Heritage, Adaptive Reuse and Regeneration in Retail Design

Peer-reviewed author version

PLEVOETS, Bie \& VAN CLEEMPOEL, Koenraad (2016) Heritage, Adaptive Reuse and Regeneration in Retail Design. In: Petermans, Ann; Kent, Anthony (Ed.).

Retail-Design: Theoretical Perspectives, Routledge, p. 114-134.

Handle: http://hdl.handle.net/1942/22939 


\section{Heritage, Adaptive Reuse and Regeneration in Retail Design}

Plevoets, B. \& Van Cleempoel, $K$.

Working with existing buildings for continued use has become increasingly important in contemporary architectural practice. The reasons for this are multiple, ranging from the need for sustainable development patterns, current economic climate's need for less costly physical architecture and an ever-increasing awareness of the benefits of retaining our architectural heritage. All of this adds to the importance of what can be called 'adaptive reuse'. Although a widely accepted definition of 'adaptive reuse' seems to be lacking (for an overview see: Plevoets and Van Cleempoel, 2013; Plevoets, 2014), it implies (partly) changing the function and programme of a building, as well as physically adapting the building to new needs and requirements. The term may refer to altering buildings with heritage value - protected or not protected - or to 'ordinary' buildings without historical or architectural value. In what follows we focus on adaptive reuse of heritage buildings (both protected and non-protected), although several arguments are also applicable to the general building stock.

In historic city centres, adaptive reuse of the existing buildings for retail and other commercial functions is a frequently occurring practice. However, seen from the point-ofview of the retail sector, dealing with historical buildings is not an easy task. Usually there are many stakeholders involved in retail-reuse projects, all with different interests: (governmental) agencies involved in conservation are primarily interested in the preservation of the heritage values of the building, while investors are mainly interested in the revenues of the project. However, reusing heritage for retail can also be an opportunity for both sectors.

In this chapter we elaborate on the challenges and opportunities of using and reusing heritage for retail. We do so through three concepts that underlie today's retail design theory and practise, but which are at the same time at the core of contemporary discussions related to heritage preservation: identity, authenticity, and sustainability. For each concept, we illustrate our argument with examples from practice and relevant literature.

\section{Heritage and Identity}

European urban and rural landscapes are strongly shaped and characterised by its historical architecture. This physical condition includes countless heritage sites that, in a way, have shaped Europe's identity. Different perhaps than in most other continents, the European landscape has grown historically, building upon structures and sites that have been passed on from one generation to another for centuries, adapting the landscape and its structures and sites to changing social, economic, cultural or political circumstances, and people's needs and desires. This process occurred spontaneously, mostly because of practical and economic reasons - reuse was cheaper and faster than new constructions - and was not directly intended as an act of conservation of cultural heritage. But nevertheless, this process has created a strong sense of cultural and historical continuity. Based on that, the notion of 'heritage conservation' has been developed in Europe, mainly from the nineteenth century onwards; and also during the twentieth century Europe continued to play a major role in the 
development of concepts that underlay the theory and practice of heritage conservation worldwide (Choay, 1992; Jokilehto, 1999). In the Burra Charter, conservation is described as 'the processes of looking after a place so as to retain its cultural significance' (ICOMOS Australia, 2013, article 1). Up to the 1990s, the interpretation of 'cultural significance' was limited to tangible aspects - the authentic material evidence - and as such, the process of conservation allowed only limited change to the building. Since the last decades, however, also intangible aspects such as narratives, rituals, and uses are considered important heritage values and part of the cultural significance of a place. This resulted in a broadening concept of conservation, which may include:

... retention or reintroduction of a use; retention of associations and meanings;
maintenance, preservation, restoration, reconstruction, adaptation and
interpretation; and [the practice of conservation] will commonly include a
combination of more than one of these. Conservation may also include retention
of the contribution that related places and related objects make to the cultural
significance of a place (ICOMOS Australia, 2013, article 14).

Today, the European built environment has been largely defined by this 'conservational' approach, and new development projects unavoidably have to deal with the present historic fabric. Retailers for instance have no choice but to deal with the existing (historic) context: single shops on primary locations in historical city centres are usually located in historical buildings, while shopping centres and other types of large-scale retail development projects are often located in existing sites which lost their original use (such as former industrial sites) or which architecture has to be adapted to the existing (historic) context (English Heritage et al., 2005). There are, however, two approaches of dealing with heritage conservation and reuse: on the one hand, there is a problem-based approach in which the historic fabric is seen as a limitation towards the implementation of contemporary retail design; on the other hand there is an opportunity-based approach, in which heritage is used as a way to construct a particular retail branding, or to evoke a unique customer experience.

Within the problem-based approach, the retailer considers the typology and characteristics of the given heritage building or site as a limitation for the implementation of the retail design. In many (European) countries, the practise of conservation is strongly controlled by the government and specific agencies such as English Heritage in United Kingdom, the 'Commission nationale des monuments historiques' in France, or the Agency Immovable Heritage in Flanders. These agencies oversee all works on protected buildings and sites in order to preserve its cultural significance. In practice, this usually results in restrictions towards physical adaptation of the building, for example as to the creation of store windows and attachment of publicity on the façade of the building, or as to horizontal and vertical circulation and the use of certain materials and finishings in the interior.

In many historical centres, however, commercial development and the process of retail-reuse is already going on for decades. In the past, restrictions towards adaptation of the existing fabric was often limited to the exterior of the building - the façade - and as a result the 
interior structure and interior features have become invaluable from a heritage-point-of-view. Therefore, façadism - the process of demolishing a building but leaving its façade intact for the purpose of a new structure in, around, or behind it (Richards, 1994) - became a frequently occurring practice. Although this approach is in general not supported by conservation policies today, in historical centres where pressure for development becomes stronger, this practice still occurs frequently and is often allowed by local urban planning departments.

Beside a problem-based approach, there is also an opportunity-based approach towards heritage, which considers heritage as a valuable asset, a capital of irreplaceable cultural, social, environmental and economic value (CHCfE Consortium, 2015). Starting from that assumption, some retailers use the historic building in which they are located - its tangible aspects, but also its intangibles aspects such as narratives and atmosphere - as a differentiation strategy. In today's society, the purpose of consumption is not merely anymore to satisfy needs or wants, but also to construct a social identity (Ogle et al., 2004). Beside the product at sale, an important factor for retail branding is the physical retail environment and the design of the retail space (Kent, 2007). Michel Van Tongeren puts it this way:

A store environment is the ideal medium for communicating the values of a retail brand with great precision. The consumer can see, experience, touch and smell it; he has chosen to be there at that moment and is therefore highly receptive to it. Which is very different than watching a remote commercial in your own cluttered living room (2003).

When consumers visit a store, they immediately make an association between the products sold in the store, their price, the store's 'tone of voice' and ambience, and the retailer's presence and identity. As a result, the retail environment and retail branding cannot be disconnected from one another (Van Tongeren, 2003, 2004). Still, the particular relationship between historic architecture - heritage - and retail design has only received limited attention by scholars so far. Kirby and Kent (2010a) examined the link between retail store architecture and the communication of brand identity through case studies of four food superstores in the UK. They found four strategies, which may be applied to communicate brand identity. However, they did not include reuse of historic buildings as a means for retail branding. In another study Kirby and Kent (2010b) recognize reuse of historic buildings as a means for place branding. Warnaby (2009) investigates the potential for historical architecture to contribute to the experience enjoyed by the retail users of towns and cities, but he finds that very often, the retail design of the interior and exterior of the store does not incorporate the historic characteristics and features of the surrounding historic fabric; as such, seen from the ground floor, there is little that differentiates these historic districts from similar retail areas elsewhere. Starting from a similar observation, Onay (2013) studied a number of case studies of antique buildings in Florence of which the ground floor is transformed into a shop. She finds that most problems arise on technical aspects - integrating technical installations such as heating and lighting in an existing historic building - and on aspects of brand identity incorporating the historical atmosphere of the host space in the retail branding. 
Hyllegard, Ogle and Dunbar (2006) explored the relationship between consumers' identities and their responses to retail design at the Recreational Equipment Incorporated (REI) flagship store in Denver. Although the store was located in a former industrial building, the research's primary focus was on aspects of sustainability and not on historical features. Also Rubessi (2010) has analysed different case studies of retail design in historical buildings within the framework of ecological design. Brown and Maclaren (2005) studied consumer experience in the case study of Powerscourt Townhouse Center, a shopping centre located in a historic building. Their study demonstrated that prioritising commercialization over preservation of the genius loci - the spirit of the place - is detrimental to the consumer experience. Building further on that we analyse how reusing the historic fabric may be an added value for the retailer in the context of retail branding. Therefore, we recognize two different levels on which heritage can make a possible contribution towards retail branding: firstly on the level of the individual store located in a historic building; and secondly on an urban level, regenerating larger historical sites or districts into retail areas.

\subsection{The historic building as a component in constructing a store identity}

Instead of focussing on its limitations, some retailers perceive an historical building as a valuable asset and a way to construct a particular store identity. Being located in an historical building may render the offerings more 'authentic', and evoke an emotional experience from the customer. Some brands intentionally look for historical buildings for locating their store.

An example of such brand is Apple. Indeed, as a brand, Apple has been very succesful in constructing a strong identity. Their flagship stores - the so-called Apple Stores - are an important feature in this. Instead of a traditional retail space oriented towards selling goods, Apple Stores are organised as public spaces where people can see, touch and learn about Apple products; the stores are conceived as places for strolling, where people can meet and are always centrally located in city centres (Gallo, 2012). Where in the United States, Apple Stores were usually built as new constructions incorporating very advanced construction techniques and materials, in Europe the stores are often located in historical buildings; examples are Covent Garden (London) in a former industrial building, The Hague in a ninetheenth century shopping arcade, Opera in Paris in a former bank, and Amsterdam and Kurfürstendamm Berlin, both in a neoclassical listed building. In each of these stores, they applied a similar design strategy, which is to restore the historical façade of the building as well as preserving the remaining historical features in the building's interior. However, the newly integrated elements such as staircases, furniture, and signing are the same as in any other Apple Store. As such, all stores retain a very characterizing and easy recognizable image.

(Insert figure 1 about here; reference: photograph availble from wikicommons, made by Cristian Bortes, free from copyright)

Another brand that has intentionally looked for unique, existing buildings to locate their stores is the avant-garde fashion line Comme des Garçons. Comme des Garçons is widely credited to have invented the concept of 'guerilla' or 'pop-up' stores. Guerrilla stores are stores that 
pop up unannounced, move into an empty building in a large city, transform the space into a trendy store to then disappear again after a few months; different than flagship stores, they are usually off the main shopping street (Dowdy, 2008). The first guerilla store by Comme des Garçons opened in 2004 in Berlin. In the following years, temporary shops were opened in exocentric, but vibrant cities such as Krakow, Warsaw, Athens, Cologne, The Hague and Beirut. Unlike the Apple Stores, each of the Comme des Garçons guerilla stores have an absolutely unique outlook. Rather than disguising a building's former use, they often plat it up; they are not 'designed' but rather seemingly thrown together by art students or some such (Van Cleempoel, 2008; Dowdy, 2008). On the guerilla store website, Comme des Garçons discribe their concept as follows:

1. The guerilla store will last no more than one year in any given location

2. The concept for intrior design will be largely equal to the existing space

3. The location will be chosen according to its atmosphere, historical connection, geographical situation anyway from established commercial areas or some other interesting feature

4. The merchandise will be mix of all seasons, new and old, clothing and accessories, existing or especially created, from Comme des Garçons' brands and eventually other brands as well

5. The partners will take responsibility for the lease and Comme des Gaçons wil support the store wil the merchandise on a sale or return basis (Comme des Garçons guerilla store, 2005)

Their store in Cologne (2005-2006) was located in a former butcher's shop - Neffgen - a family-run company established in the 1950's. The atmosphere of the former butcher's was completely preserved; even the original name was not removed from the façade. The original butcher's shop fixtures and fittings were used to hang the clothes. In 2008, when the concept of guerilla stores had been taken over by many other retailers and brands, Comme des Garçons terminated their guerilla store concept.

(insert figure 2 about here; permission is requested to photographer Kira Bunse but we are still waiting for her confirmation)

\subsection{The historic district as a retail area: branding the city}

The cultural and physical character of our towns and cities has always been influenced by the commercial activity they accommodated (English Heritage et al., 2005). But the nature of shopping and trading has changed radically in the course of time and consequently influenced the physical retail environment: e.g. demand for bigger shop units, rise of chain stores at the expense of the independent retailer, need for vehicle access for shoppers and servicing and demand for greater security (English Historic Towns Forum, 2008). These requirements present considerable challenges to historic towns. Jokilehto (1985) illustrates the tension between retail development and authentic preservation of historic fabric with the example of the historic town of Lübeck which could not be accepted to the World Heritage List because too much of its fabric has been lost due to - among other reasons - uncontrolled commercial 
development. He concludes that in order to avoid unnecessary pressure for change and destruction, it is important to plan the type and scale of commercial and other activities for historic towns in a way that these can be absorbed by the historic structure, with respect for its identity.

But reusing historic buildings for retail may advance the viability of historic centres and as such may stimulate urban regeneration. Kirby and Kent (2010b) state that reuse of the city's architectural heritage can act as part of the city's image and its city branding. They explain that the purpose of city branding is to promote a city for certain activities and in some cases sell parts of the city for living, consuming and productive activities. An often-applied strategy is to orientate the city branding towards reworking, repackaging and re-presenting historical and existing cultural qualities of the city. Murzyn-Kupisz (2013) studied the impact of private commercial investment in historic monuments and she finds that restoration and reuse of heritage buildings prove a crucial impulse to start and inspire regeneration of the village or town centre, and contributes to its 'image' or 'branding'.

An example of a city that differentiates itself through heritage is Łódź, a former industrial city in the centre of Poland, where many industrial sites became abandoned after the textile industry fell down in the 1980s. As the city largely developed through its industries, the city lacked a pre-industrial past. Łódź did not have earlier monuments, and after the collapse of its industries the city also needed a revitalisation of its buildings stock and redefinition of its identity (Sowinska-Heim, 2013). In 2006, one of the largest former factories in the city was transformed into a mix of shopping, hospitality, leisure and cultural functions. The project, called Manufaktura, includes the restoration of existing buildings - mainly applying the concept of façadism - as well as new constructions. As there has been a lack of wellorganized public space in the centre of Łódź, major attention was given to the creation of a central square. In the years following the opening of the project, other initiatives of adaptive reuse of industrial sites by private investors have been realized in the city centre. Today, Manufaktura strongly contributes to upgrade the image of Lódź within Poland and beyond. The city also explodes this newly created image as a 'brand' for Łódź (Wycichowska, 2008), as a way to attract new investors, tourists, and inhabitants. However, as argued by Julia Sowinska-Heim (2013), the project is primarily a commercial project that only tells a positive past; the newly created image is completely artificial and does not correspond in any way with the 'authentic' atmosphere of the nineteenth century textile factory it refers to.

\section{Authenticity versus Disneyfication}

Since the adoption of the World Heritage Convention in 1972, authenticity is used as a way of evaluating the preservation and adaptation of heritage sites (Starn, 2002; Stovel, 2007). Semantically, the word 'authentic' refers to the Greek authentikòs (autòs, myself, the same) and the Latin auctor (an originator, authority), and thus to 'original' as opposed to 'copy', 'real' as opposed to 'pretended', 'genuine' as opposed to 'counterfeit' (Jokilehto, 1999). Being authentic is having authority, being trustworthy, credible, convincing, real, genuine or original (Webster, 1986). 
The last decennium, authenticity also has become an important marketing strategy in diverse economic sectors such as (heritage) tourism, hospitality, leisure and retail. As competing in today's global market is becoming increasingly difficult since customers often perceive products and services as homogeneous, retailers try to be seen by customers as being original, trustworthy, or 'authentic' (Petermans and Van Cleempoel, 2009; Pine and Gilmore, 2007). Locating one's store in a historic building can be a way for retailers to render their store and/or product as being authentic (Plevoets et al., 2010). An example of a historical retail building typology that has received increased interest by retailers and consumers in the context of authenticity is the arcade or 'passage'. In different European towns, examples of this building type that date back to the nineteenth century still exist and regained popularity the last two decades as places for shopping and strolling around. In the Galleries Saint-Hubert in Brussels, for example, Belgian retailers and brands occupy several of the stores because they want to present their 'traditional' and 'local' products in this particular 'authentic' retail setting; examples are chocolatier Neuhaus or Delvaux leatherwear. In the Galleria Vittorio Emanuele II in Milan, many Italian fashion brands such as Prada and Versace occupy central locations in the arcade (Plevoets and Van Cleempoel, 2011).

The meaning of authenticity, however, is understood differently within the context of heritage conservation as in marketing and retailing. In the field of heritage conservation, authenticity of a building or site is linked to the values attributed to it. Although the interpretation of these values may differ based on the cultural context in which they are evaluated and may evolve over time, the concept of authenticity is considered to be a 'scientific' and 'objective' criterion for protection, conservation and restoration of heritage (e.g. ICOMOS, 1-6 November 1994; UNESCO, 2008). Contrarily, in the field of marketing, the concept of authenticity is equally linked to values but on a very personal, intuitive and subjective level; offering an authentic customer experience implies appealing to customers' senses, emotions and values with the aim to create personal, intuitive relationships with the specific brand or retailer (Petermans, 2012). In the field of marketing, authenticity is also being used as a true 'means' that retailers employ with the aim to try to differentiate their brand from competitors. However, as the experience of authenticity is personal and subjective, Pine and Gilmore (2007) state that in order to render a brand as authentic, the values communicated by that brand should be consistent on all different levels: its products, services, relationships, and (retail) places.

Several studies have explored why and when customers perceive products as 'authentic' versus 'fake' (e.g. Lin and Wang, 2012; Lunardo and Guerinet, 2007; Starr, 2011). However, only a limited number of studies have analysed the authentic experience in relation to the retail space (Maclaran and Brown, 2005; Peñaloza, 2001). In what follows we illustrate different 'degrees' of authenticity and how they can be applied in retail design.

\subsection{Authenticity: the staged, the faked, the hyperreal, and the simulacrum}

Based on these diverging interpretations of the concept, what is considered an 'authentic experience' from a consumer's point-of-view may be seen as inauthentic from a conservator's 
perspective and vice versa. MacCannell (1973) introduced the term 'staged authenticity' - by other authors later referred to as 'fake authenticity' (e.g. Pine and Gilmore, 2007) - in the context of heritage tourism to appoint to experiences that are arranged in order to give tourists the impression to being able to interact with native people. MacCannell (1973) explains though that 'true authenticity' versus 'staged authenticity' are two poles of a continuum, that many nuances and interpretations may exist and that, besides tourist settings, his theory also could be applied to other domains of social life. Following MacCannell's idea, several authors have developed a classification of authentic experiences in different contexts (e.g. Grayson and Martinec, 2004; Pine and Gilmore, 2007; Plevoets et al., 2010; Thimothy and Boyd, 2003).

The differentiation between the 'fake' and the 'real', however, is much older than MacCannell's work, as it can be traced back to Plato's theory of Ideas which distinguished the true (metaphysical) object and its image, the original and the copy, the model and the simulacrum, the authentic and the inauthentic. Plato's distinction moves between two sorts of images: on the one hand iconic copies - well-founded images of the Idea, endowed with resemblance, 'modelled' in the Idea itself; and on the other hand phantasmatic simulacra insinuations, subversions, which are made without passing through the Idea (Deleuze, 1983).

The theory on simulacra has been applied by Baudrillard within his critic on consumer society. In contrast with Plato, Baudrillard does not believe in objective reality or truth but only in the individual interpretation of it (Lepers, 2009). According to Baudrillard, we live in the era of simulation, inaugurated by a liquidation of all referentials: the model of the real has no origin or real anymore. It is no longer a question of imitation, nor duplication, nor even parody. He describes this 'decay of the real' in four steps:

'Whereas representation attempts to absorb simulation by interpreting it a false representation, simulation envelops the whole edifice of representation as itself a simulacrum. Such would be the successive phases of the image:

- It is the reflection of a profound reality

- It masks and perverts a profound reality

- It masks the absence of a profound reality

- It bears no relation to any reality whatever: it is its own pure simulacrum' (Baudrillard, 1994)

In Baudrillard's view, this final phase is supposed to supersede all others; where in the first phase there is still a 'real' to refer to, in the final phase simulation no longer copies anything and reality is replaced by nostalgia which is the plethora of truth, of secondary objectivity, and authenticity (Hegarty, 2004).

Baudrillard argues that in the era of nostalgia, reality is replaced by hyperreality. He refers to Disneyland, among many other examples, as a perfect model of the hyperreal. In the first place, Disneyland is an imaginary world, which ensures the success of the operation but it is also a social microcosm, a miniaturized pleasure of real America. Disneyland is presented as imaginary in order to make us believe that the rest is real (Baudrillard, 1994). The term 
'Disneyfication' - sometimes also called 'Disneyization' - came into use to describe hyperreal places created to transform cultural capital in economic capital (Harris, 2004), and has been applied in heritage tourism and retail design. Characteristic to 'disneyficated' places or sites is the fact that they are 'themed' around one particular narrative, instead of presenting its various layers or narratives (Bryman, 2004).

An example of such a disneyficated 'heritage site' is Bataviastad, an outlet shopping village in the Netherlands, created as a themed park around the shipyard of the 17th century vessel 'Batavia'. The design of Bataviastad is conceived as a reconstructed fortified town; aesthetically the village is a pastiche of historicised architectural elements inspired partly on Marken Island and partly on colonial architecture from the Caribbean where the original ship Batavia used to sail to (Groenendijk and Vollaard, 2006). Next to the fashion outlet there is the Batavia Yard Museum where visitors can go on-board on the 'authentic reconstruction' of the ship Batavia (Bataviastad, 2015). Although Bataviastad is definitely 'inauthentic' or 'fake' from an heritage point-of-view, it might nonetheless generate an authentic customer experience as the notion of authenticity in that sense is not objective, but personal and individual. Indeed, even if consumers do know that the visited site is only an 'imagined', 'simulated' or 'disneyfied' world, as shown by Grayson and Martinec (2004), this does not necessarily render their experience less authentic.

\subsection{The simulacrum as an aemulatio of the original: an opportunity for retail design?}

In his article Plato and the simulacrum, Deleuze takes the theory on simulacra even further than Baudrillard (Deleuze, 1983). He starts from a similar definition of simulacrum as Baudrillard but he undermines the very distinction between copy and model. In Deleuze 's view, the simulacrum is not a degraded copy, rather it contains a positive power which negates both original and copy, both model and reproduction; the simulation is a process that produces the real. Deleuze describes the era of simulation as the 'overthrow of Platonism', which means to raise up simulacra, to assert their rights over icons or copies.

In the context of heritage conservation and restoration, the term simulacrum has often been used to point to restoration-works that are not based on solid evidence but rely on an impression or an idea of the original architecture or style (e.g. Brilliant, 2011; Hodges, 2009; Labadi, 2010; Mack, 2011; Scott, 2008; Theodoraki et al., 2009). A heavily criticized project in that sense is Viollet-le-Duc's restoration and reconstruction of the fortification of Carcassonne as it would be based on assumptions of the architect rather than on scientifically obtained evidence (e.g. Brilliant, 2011). However, in the book Heritage and Globalisation, Labadi (2010) states that, based on the definition given by Baudillard, in practice all works of restoration are in fact a simulacrum; historic buildings, sites and towns are hardly ever 'frozen' in time, but are subject to their social, economic and political context. As such it is impossible to bring back the building to its original condition. Hodges (2009) adds to that that artefacts restored or reconstructed as a 'simulacrum of an imagined former state', although not being authentic in a material way, have the potential of showing other aspects of authenticity such as for example craftsmanship. His approach corresponds to Deleuze's approach of the simulacrum holding a positive power in contemporary society. 
In his book 'On Altering Architecture', Fred Scott (2008) pleads for a break regarding the taboo of copying that currently exists in relation to heritage conservation. He argues that in other art forms such as music and painting, copying has long been considered a serious activity; like the composer or the painter, the designer may find a source of sustained inspiration through the act of "copying". Throughout history, and during the Renaissance period in particular, imitation or copying of both nature and the Old Masters was highly valued in the fields of literature and art, and the particular relationship between the model and the copy has been subject of much philosophical and artistic debate. Building further on Scott's concept of copying and improving as a valuable strategy for adaptive reuse, we have introduced the concept of 'aemulatio' (Plevoets and Van Cleempoel, 2014). Aemulatio is a concept from renaissance art theory to refer to a particular type of copying that has been used in literature and visual arts and that aims at improving its model, rather than duplicating or interpreting it. In the context of adaptive reuse, we have used this term to describe projects that do not merely reconstruct or 'copy' the original features of the building, but that instead try to surpass the original aesthetically as well as functionally, and as such create an aemulatio of the original host space.

An example of such project is The Hague's Raad Van State (Council of State) by design office Merkx+Girod. Instead of restoring the original interior of the building or introducing a contemporary interior, the new interior attempts to surpass the original aesthetically as well as functionally, and as such creates an aemulatio of its model. The Empire style of the ballroom inspired the designers to find contemporary solutions to evoke the same luxurious and sophisticated atmosphere. The chandeliers, as with all other lighting fixtures, are customized for this room; they are composed of glass beads, some of which contain small slices of gold in order to produce a brilliant light. The columns in stucco antico, the gold leaf on the stucco of the ceiling, and the preservation of the symmetrically placed mirrors in the room all contribute to the brilliant atmosphere. Several of these features were created in collaboration with artists and craftsmen.

This approach, however, is new to the field of adaptive reuse and conservation and examples projects that create an aemulatio through the process of adaptive reuse are scarce and usually linked to cultural programmes. But the concept might hold a lot of potential for the retail design discipline as it aims to preserve the buildings' 'atmosphere' rather than its material features, and as such is strongly directed towards an 'authentic experience' of the host space on an individual level.

\section{Sustainable Retail Design}

In Europe, the process of adaptive reuse is closely linked to heritage preservation and revitalisation of historical centres. However, besides a method for dealing with heritage buildings, adaptive reuse is also a valuable instrument for sustainable development. In that sense, adaptive reuse becomes a discipline of interest not only in a European context, but also in a global perspective. As demolition and construction are by far the largest producers of waste - in the UK, twenty-four per cent of the total waste material (Clark, 2008) - reducing 
waste is vital for creating environmentally responsible buildings and interiors. Reusing existing buildings is intrinsically respectful towards the environment because the amount of resources needed for reuse is far less than those needed for new constructions. Moreover, when the existing building is historically or architecturally significant, it provides a link to our cultural and collective memory (Brooker and Stone, 2008). As adaptive reuse is considered highly sustainable - environmentally and socially - a first step towards sustainable retail design is reusing an abandoned historic building.

\subsection{What is sustainable design?}

The word sustainable refers to the Latin sustinere (tenere: 'to hold' and sus: 'up'), or sustainable means 'to be maintained', 'endured' (Webster, 1986). Today, sustainability has often been approached as being ecologically responsible or 'being green' (USGBC, 2010; Cassidy et al., 2003; Public Architecture, 2010; Yudelson, 2009). Douglas (2006), however, makes a distinction between 'sustainable construction' and 'sustainable development'. Sustainable construction is concerned with minimizing construction waste and pollution, saving energy, increasing the use of recycled and locally produced materials and relying less on toxic chemicals. Sustainable development deals with urban, and regional and local issues such as development densities, (public) transport and land-use. It includes social planning issues such as creating workplaces and housing near each other to reduce waste and minimize transport problems. In an ideal situation, 'sustainable design' covers both approaches - it implies sustainable construction including efforts for being green, taking into account sustainable development aspects such as urban planning and regional identity.

However, the definition adopted by the Brundtland Report that sustainable development 'implies meeting the needs of the present without compromising the ability of future generations' (United Nations, 1987, p.1) covers a much broader interpretation of the term including social and economic issues. In The Philosophy of Sustainable Design McLennan (2004) says:

\section{A lot of buildings and building products get designated green or sustainable because they contain a few features that lower their environmental impact to some degree. Sustainable design is not about features. ... [Instead] Sustainable Design is a design philosophy that seeks to maximize the quality of the built environment, while minimizing or eliminating negative impact in the natural environment.}

He argues that as the word sustainable means 'to be maintained', it does not necessarily imply the need to change the way wherein we relate to the natural world. He believes that instead of 'sustainable design', 'restorative design' would better cover its meaning. In that sence the most sustainable buildings as those that have been designed decades, or even centuries ago, but which are still in use today without having encountered major alterations to its physical structure.

Manzini (2012) takes the discussion even a step further. He argues that only through a radical social innovation we can move towards a more sustainable society. Where design has in the 
past being part of the problem - massproduced products that were not intended for rapid consumption - it might become part of the solution as design holds the power to change the way in which people live and interact with their surroundings. Sustainble design in that sense could be a catalyst for changing the actions of different social actors in a more sustainable direction.

\subsection{The tension between sustainable design and retail design}

Reducing waste is vital for creating environmentally responsible buildings and interiors. Even more than architecture, interior architecture (and in particular, retail design) is often seen as temporary as it anticipates current fashion and personal taste. Indeed, many interiors have a very short lifespan, ranging from a few days for scenografic installations to a few years for retail, to one or two decades for domestic interiors (Douglas, 2006). As a consequence, there is a strong tension between interior architecture and sustainable design (Tucker, 2015). In the retail sector, this tension seems to be most striking; retail is easily associated with patterns of mass consumption and increased ecological footprint as a larger share of the world's environmental problem is caused by individual and aggregate increases in human consumption (Maté, 2013; Schaefer and Crane, 2005). On product level, efforts have been made towards the use of environmentally responsible materials for producing and packaging of products at sale (Cha, 2001; Maté, 2013) but, to stay competitive and appealing to customers, many retail interiors are being updated on a regular basis. This rapid change of interiors, however, produces tonns of construction waste.

In order to reduce construction materials, and consequently the proportion of waste, retailers and retail designers started to work with reused materials to furnish, or even to construct their stores. An example is the Third Wave Kiosk on the cost line of Torquay, Australia. The kiosk is not located in a retail area but needed to be integrated in the landscape of the costline. Therefore, the designers Hobba Architects chose a material with a strong patina for the construction of the kiosk - recycled sheet piles typically used for seawall, bridge and pier construction -, so that it seems to merge with the surrounding landscape. But also the guerilla stores by Comme des Garçons (supra 1.1) are an example in this respect, as they usually add almost nothing to the existing building, except for some reclaimed materials from secound hand shops or garbage dump.

(insert figure 3 about here; permission and larger file is requested at the architectural office that designed the kiosk)

Using recycled or reclaimed waste materials for retail design will not be sufficient to make the retail (design) sector truly sustainable. In a recent publication, Tucker (2015) pleas for a stronger link between interior architecture and sustainable design, whereby it should be selfevident for designers to get inspired by the genius loci of a particular architectural space at a particular location, and work generously with the present situation. In her view, history can inform and inspire designers in what they do today. 
The last decade, several rating systems have been developed in order to evaluate the design of buildings and interiors as to their performance on sustainability. Today, the two leading certification systems are Leadership in Energy and Environmental Design (LEED), with 72.000 certificated buildings, and Building Research Establishment Environmental Assessment Method (BREEAM), with 425.000 certificated buildings (Green Building Council, 2015; BREEAM, 2015). Both have developed a certification system for new constructions as well as for the redesign of existing buildings in order to help a growing number of owners and tenants in defining strategies for acting sustainable. Both systems developed a quantative analysis to attach a score to a particular project.

In 2010, 'LEED for Retail certification system' was introduced to address the unique challenges faced by the retail industry. Within LEED, there are in fact two - slightly different certification systems specifically focussing on Retail: one for New Construction and another for Commercial Interiors. Both present six categories to measure how environmentally friendly a retail building or interior is (USGBC, 2010):

1. sustainable sites

2. water efficiency

3. energy and atmosphere

4. materials and resources

5. indoor environmental quality

6. innovation in design

Each category is again subdivided in a number of credits with an attached score. The total sum of credits in each category gives a score. BREEAM does not have a certification system for retail programmes in particular but thus also differentiate between 'BREEAM In-Use' for assessing the renovation of existing buildings, and 'BREEAM New Construction' (BREEAM, 2013). The rating system and analysed categories are very similar to the LEED certifications.

For the LEED system, building reuse is only mentioned in one category of both lists (materials and resources). In the 'Commercial Interior' list it accounts for 1 credit out of 110 credits in total; in the 'New Construction' it is mentioned twice for a maximum of 4 credits out of 110 (USGBC, 2010). We believe, however, that this is too limited and that adaptive reuse can contribute stronger to sustainable retail design, not only in an ecological way but also in a economic and sociological way by including aspects such as community involvement, social employment programmes, expected and actual lifetime of the building and its interior.

\subsection{Adaptive reuse as a strategy for sustainable design}

Although these certification systems are very useful in stimulating sustainable design, Alan Durning (1999) explains that the only efficient measure for creating an environmentallyfriendly society would be a shift towards what he calls 'post-consumer lifestyle'. Herewith, he means that we have enough material comforts but we should try to make them last longer. His idea is not only relevant on product level, but also with regards to the physical environment. 
Except for the recycling of scraped materials and products, adaptive reuse of existing buildings is another way to work on such a 'post-consumer lifestyle'.

One of the most famous and iconic examples of adaptive reuse of a heritage building for retail is probably the bookshop Dominicanen in Maastricht (The Netherlands) - fomerly Selexyz Dominicanen. The project, which involved the transformation of a Medieval Gothic church into a bookshop, was widely published in national and international press and was even proclamed as the 'most beautiful bookshop in the world' by the Guardian in 2008 (Dodson, 2008). The bookshop opened in 2006 and upto now, only very limited changes have been made to its retail design. In contrast with the tradional notion of retail design being very fashionable and rapidly outdated, in this particular case there seems no need to change the store's interior as the iconic design of the building has become part of the retailer's image or branding.

English Heritage takes the idea of adaptive reuse of heritage as a strategy for sustainable design even one step further. They state:

The re-use and adaptation of heritage assets is at the heart of sustainable development. Not only does re-use lessen the amount of energy expended on new development, but heritage can be used to boost local economies, attract investment, highlight local distinctivenes and add value to property in an area (English Heritage et al., 2004).

The above described case of Manufaktura in Lódź (supra 1.2) is a clear example of the commercial reuse of heritage that generated a boost for local economy and development. Yet, historic buildings often perform poorly in terms of energy efficiency and, as such, are not invariably beneficial in ecological terms. This causes particular technical challenges to architects, interior architects and engineers dealing with adaptive reuse, which has led to the development of extended theories and studies on technical aspects of adaptive reuse.

\subsection{Generosity and sustainable design: an intrinsic relationship}

Contrary to the project of Manufaktura that involved major remodelling works on existing buildings and several new constructions on the site, the ultimate sustainable interiors are those that have survived the course of time and remained unchanged since their creation. One example is Adolf Loos's (1870-1933) design in 1910-13 for Knize, one of the world's leading labels for stylish menswear at the time, in Vienna (Germany). The storefront is rather narrow and is made from black Swedish granite with an entrance door and display window worked in fine cherry wood. The actual store is surprisingly spatial, with an extension on the first floor. Characteristic interior features are the dark oak panelling, glass display cases, a brick fireplace, oriental carpets, and English leather armchairs. The Knize store is preserved in its original state and is still used today. In addition to this first store, Loos also designed stores for Knize in Karlsbad (1921), Berlin (1927), and Paris (1927-28), but they were not preserved (Sarnitz, 2003). 
The example of Knize, however, is a rather unique one. Usually these kind of interiors change as well as the people that use them. Nevertheless, some buildings enjoy the intrinsic ability to easily host functions other than the ones for which they were originally built. Such buildings can be reused, without the need for major adaptation works. The term 'host space', introduced by Brooker and Stone (2004) and later adopted by Scott (2008), refers to the generous quality of a given building, which is open to 'host' new functions and users. Such 'generous buildings' are exemplary for sustainable design, and do exist within the field of retail design. The above-described nineteenth century shopping arcades that are still in use today (supra 2) are a clear example. Another example is the former Chemiserie Niguet in Brussels (Belgium), designed by the art nouveau architect Paul Hankar (1858-1901) in the late nineteenth century. Today, the store is used by Daniel Ost, a floral artist and sculpturer. He had the building restored in all its details, not only the façade and the shop front but also the interior features (Heymans, 2006). Nature as inspiration is one of the main characteristics of art nouveau, which resulted in curved lines and flower and plant decoration; as such, the historic architecture and interior fits perfectly with the creations of Daniel Ost.

As a designer - planner, architect or interior architect - we should try to create buildings and places that have generosity as an intrinsic characteristic; not only related to the field of retail design, but all fields of contemporary design practice.

\section{Conclusion}

Retailers have often applied a problem-based approach in dealing with heritage buildings. However, an opportunity-based approach holds much potential for different types of retailers and retail designers - from small independent shops to large shopping centres or flagship stores by international brands.

One of the primary goals of heritage preservation is to transfer the identity of a particular place or community to the next generations. The buildings that we have inherited from the generations before us are indeed endowed with tangible (e.g. materials, typologies, crafts) and intangible references (e.g. narratives, and atmospheres) of our collective, and sometimes also personal memory. As a retailer, working with heritage might in that sense be an opportunity to establish a brand or store identity that merges with a particular building or site. This can be performed in a general sense, such as in the case of Apple Stores, whereby the historical structure and façade of a building is reused and incorporated into one's retail design. But it can also be in a very specific way, such as in the case of the guerrilla stores of Comme des Garçons, which often reuse the complete host setting 'as found' and seem to add no 'retail design' at all. Furthermore, next to the level of the single building, reusing heritage for retail can also contribute to the branding of the city as a whole, as for example in Łódź (Poland). For town or regions without an historical centre, an heritage setting is sometimes staged or faked in order to create an 'authentic customer experience'. Examples within the field of leisure design are theme parks or themed restaurants; examples from retail design are retail outlet centres. This strategy of 'faking' an historical setting for commercial interests was first applied outside of Europe, in United States and later in Asia, but is now occasionally 
applied in a European context as well. Indeed, a 'hyperreal' heritage setting does not bring on the same difficulties and limitations, as a 'real' heritage setting.

Where since the 1990s retail design has been focused on offering memorable, 'spectacular' experiences to customers, the last decade there has been a shift towards experiences that are less spectacular at first sight, but that are instead deeper, more 'authentic'. As such, authenticity seems to have become the new benchmark for branding and retail design. Working with heritage, and heritage buildings in particular, is an excellent opportunity to create or strengthen an 'authentic' retail image. However, as authenticity in retail design is very often borrowed or constructed, the offered experience is often 'staged' or 'fake'. The risk for Disneyfication of the heritage site, but also of the retail image and branding is high because often only one (positive) narrative about the site and its history is told. Outlet centres, such as Bataviastad, are an extreme example in that sense as they are often built up as theme parks, but the borders between the authentic and the fake are becoming more and more blurred, not only in the retail sector but also in the heritage sector. This, however, should not necessarily be seen as a negative evolution. The renaissance concept of aemulatio shows that copying, or improving the existing can be considered a valuable strategy for dealing with heritage buildings. Although most examples of this approach towards adaptive reuse of heritage exists in the cultural sector, we believe that the concept of aemulatio can be an opportunity for the retail sector as well, as this approach is focused on experiencing the building. Contrarily to Disneyfication that usually tells and highlights only one narrative or heritage layer, aemulatio is multi-layered and may incorporate different values and layers of the heritage building or site.

Sustainability is today a very important issue in all aspects of design, and society at large. There are good individual examples of retail design that is increasingly sustainable from an ecological point of view, but there remains a strong tension between sustainability and retail design. This can be explained to a large extent via the presence of a consumer society in many Western countries, and the enormous waste of materials and goods that is brought about with the construction of many rapidly altering retail design projects that are present in the retail market via retailers' and designers' efforts to answer a particular call from large proportions of today's consumer public. On the level of retail design, we believe that we should move towards retail designs that are less temporal and can be used for a longer time span. We therefore introduced the concept of generosity in (re)design of buildings and interiors. Examples of such 'generous' retail designs are conserved today in contemporary used nineteenth century shopping arcades, department stores and boutiques. Their quality of design, materials, construction and atmosphere seems to be timeless and (re)usable for many different generations and purposes. Such design, that has this quality of generosity, may be an inspiration for contemporary retailers and retail designers not to make fashionable and quickly renewable retail designs, but instead to strive to create stores and interiors that surpass the passage of time and remain interesting for retailers and consumers for the next several generations.

\section{Bibliography}


Bataviastad. 2015. Bataviastad Fashion Outlet [Online]. Available: http://www.bataviastad.nl/ [Accessed 7 November 2015].

Baudrillard, J. 1994. Simulacra and Simulation, Michigan: The University of Michigan. Originally published as Simulacres et Simulation (Edition Galilee, 1981).

BREEAM. 2013. BREEAM In-Use [Online]. Available: http://www.breeam.org/page.jsp?id=360 [Accessed 7 November 2015].

BREEAM. 2015. Available: http://www.breeam.com/ [Accessed 7 November 2015].

Brilliant, R. 2011. Authenticity and Alienation. In: Brilliant, R. \& Kinney, D. (eds.) Reuse Value: Spolia and Appropriation in Art and Architecture from Constantine to Sherrie Levine. Surrey: Ashgate Publishing Limited.

Brooker, G. \& Stone, S. 2004. Re-readings. Interior architecture and the design principles of remodelling existing buildings. London: RIBA Enterprises.

Brooker, G. \& Stone, S. 2008. Context + Environment, Lausanne: ava publishings sa.

Bryman, A. 2004. The Disneyization of society: Sage.

Cassidy, R., Wright, G., Flynn, L., Barista, D., Zissman, M., Richards, M., Popp, D., Nigh, L. \& James, B. 2003. White Paper on Sustainability. Building Design and Construction, November 2003. Available: http://archive.epa.gov/greenbuilding/web/pdf/bdcwhitepaperr2.pdf [Accessed 7 November 2015].

Cha, T. 2001. Ecologically Correct. In: Chung, C. J., Inaba, J., Koolhaas, R. \& Leong, S. T. (eds.) Harvard Design School Guide to Shopping. Köln: Taschen.

CHCfE Consortium. 2015. Cultural Heritage Counts for Europe. Krakow. Available from: http://www.encatc.org/culturalheritagecountsforeurope/outcomes/ [Accessed 7 November 2015].

Choay, F. 1992. L'allégorie du patrimoine. Paris: Seuil.

Clark, K. 2008. Only Connect - Sustainable Development and Cultural Heritage. In: Fairclough, G., Harrison, R., Schofield, J. \& Jameson, J. H. (eds.) The Heriatge Reader. Londen and New York: Routledge.

Comme des Garçons guerilla store. 2005. Info. Available: http://www.guerrilla-storecologne.com/thestore/\# [Accessed 7 November 2015]

Deleuze, G. 1983. Plato and the Simulacrum. October, 27(Winter 1983), pp 45-56.

Dodson, S. 2008. Top Shelves. The Guardian. Available: http://www.theguardian.com/books/2008/jan/11/bestukbookshops [Accessed 7 November 2015].

Douglas, J. 2006. Building Adaptation. Oxford: Elsevier.

Dowdy, C. 2008. One-Off Independent Retail design. London: Laurence King Publishing.

English Heritage, English Historic Towns Forum \& Planning Advisory Service. 2005. Retail Development in Historic Areas. London: Englisch Heritage.

English Heritage, RICS, British Property Federation \& Drivers Jonas. 2004. Heritage Works. The use of historic buildings in regeneration. A toolkit of good practice. London: Englisch Heritage.

English Historic Towns Forum. 2008. Focus on Retail. Bristol: English Historic Towns Forum.

Gallo, C. 2012. The Apple Experience: Secrets to Building Insanely Great Customer Loyalty McGraw Hill Professional. New York: Mc Graw Hill.

Grayson, K. \& Martinec, R. 2004. Consumer Perceptions of Iconicity and Indexicality and Their Influence on Assessment of Authentic Market Offerings. Journal of Consumer Research, 31(September 2004), pp 296-312. 
Green Building Council. 2015. This is Leed. Available:

http://leed.usgbc.org/leed.html?gclid=CPjw8pT5_cgCFSgXwwodyYoCQA [Accessed November 7th 2015].

Groenendijk, P. \& Vollaard, P. 2006. Architectuurgids Nederland 1900 - 2000 Rotterdam: 010 .

Harris, D. 2004. Key concepts in leisure studies. London:Sage.

Hegarty, P. 2004. Jean Baudrillard Live Theory. London \& New York: Continuum.

Heymans, V. 2006. Een nieuw pak voor de oude hemdenwinkel. Monumenten, Landschappen \& Archeologie, 25/4(juli-augustus 2006), pp 10-26.

Hodges, M. 2009. Disciplining Memory: Heritage Tourism and the Temporalisation of the Built Environment in Rural France. International Journal of Heritage Studies, 15(1), pp 76-99.

Hyllegard, K. H., Ogle, J. P. \& Dunbar, B. 2006. The influence of Consumer Identity on Perceptions of Store Atmospherics and Store Patronage at a Spectacular and Sustainable Retail Site. Clothing and Textiles Research Journal, 24(316-334).

ICOMOS. 1994. The Nara Document on Authenticity in Relation to the World Heritage Convention. Nara: ICOMOS.

ICOMOS Australia. 2013. Burra Charter. Available from www.icomos.org/australia/burra.html [Accessed November 7th 2015].

Jokilehto, J. 1985. Authenticity in Restauration Principles and Practices. Bulletin of the Association for Preservation Technology, 17(3/4), pp 5-11.

Jokilehto, J. 1999. A History of Architectural Conservation, 4, Oxford: Elsevier.

Kent, T. 2007. Creative space: design and the retail environment. International Journal of Retail \& Distribution Management, 35(9), pp 734-745.

Kirby, A. \& Kent, T. 2010a. Architecture as brand: store design and brand identity. Journal of Product \& Brand Management, 19(6), pp 432-439.

Kirby, A. \& Kent, T. 2010b. The local icon: re-use of buildings in place marketing. Journal of Town and City Management, 1(1), pp 80-91.

Labadi, S. 2010. World Heritage, authenticity and post-authenticity. In: Labadi, S. \& Long, C. (eds.) Heritage and Globalisation. New York: Routledge.

Lepers, P. 2009. Baudrillard. Leven na de orgie. Kampen: Klement/Pelckmans.

Lin, C. \& Wang, W. 2012. Effects of authenticity perception, hedonics, and perceived value on ceramic souvenir-repurchasing intention. Journal of Travel \& Tourism Marketing, 29(8), pp 779-795.

Peñaloza, L. 2001. Consuming the American West: Animating Cultural Meaning and Memory at a Stock Show and Rodeo. Journal of Consumer Research, 28(3), pp 369398.

Lunardo, R. \& Guerinet, R. 2007. The influence of label on wine consumption: its effects on young consumers' perception of authenticity and purchasing behavior. International marketing and trade of quality food products, (January 2012), pp. 69-84.

MacCannell, D. 1973. Staged Authenticity: Arrangements of Social Space in Tourist Settings. The American Journal of Sociology, 79(3), pp 589-603.

Mack, G. 2011. Restoration, Renovation, Reconstruction, Simulation ... Jacques Herzog on the strategic role of the Armory in Herzog \& de Meuron's approach to architecture. [Online]. Available: http://www.herzogdemeuron.com/index/projects/completeworks/276-300/293-park-avenue-armory/FOCUS/conversation-1.html [Accessed 13 August 2013].

Maclaran, P. \& Brown, S. 2005. The Center Cannot Hold: Consuming the Utopian Marketplace. Journal of Consumer Research, 32(2), pp 311-323. 
Manzini, E. 2012. The Scenari of a Multi-local Society: Creative Communities, Active Networks, and Enabling Solutions. In: Chapman, J. \& Gant, N. (eds.) Designers, visionaries and other stories: a collection of sustainable design essays. London: Earthscan.

Maté, K. 2013. Remediating Shopping Centres for Sustainability. In: Cairns, G. (ed.) Reinventing architecture and interiors: a socio-political view on building adaptation. London: Libri Publishers.

McLennan, J. F. 2004. The Philosphy of Sustainable Design. Kansas City: Ecotone LLC.

Murzyn-Kupisz, M. 2013. The socio-economic impact of built heritage projects conducted by private investors. Journal of Cultural heritage, 14(2), pp 156-162.

Ogle, J. P., Hyllegard, K. H. \& Dunbar, B. 2004. Predicting Patronage Behaviors in a Sustainable Retail Environment: Adding Retail Characteristics and Consumer Lifestyle Orientation to the Belief-Attitude-Behavior Intention Model. Environment and Behavior, 36(5),717-741.

Petermans, A. 2012. Retail design in the experience economy: conceptualizing and 'measuring' customer experiences in retail environments. Doctoral thesis, Hasselt University \& PHL University College.

Petermans, A. \& Van Cleempoel, K. 2009. Retail Design and the Experience Economy: Where Are We (Going)? Journal of Design Principles and Parctises, 3(1), pp 171182.

Pine, B. \& Gilmore, J. 2007. Authenticity: what consumers really want. Boston: Harvard Business School Press.

Plevoets, B. 2014. Retail-Reuse: An Interior View on Adaptive Reuse of Buildings. Doctoral thesis, Universiteit Hasselt.

Plevoets, B., Petermans, A. \& Van Cleempoel, K. 2010. Developing a theoretical framework for understanding (staged) authentic retail concepts in relation to the current experience economy. In: Durling, D., Bousbaci, R., Chen, L., Gauthier, P., Poldma, T., Roworth-Strokes, S. \& Stolterman, E. (eds.) Proceedings DRS2010. Montreal, Canada, July 7-9: DRS2010.

Plevoets, B. \& Van Cleempoel, K. 2011. Assessing authenticity of nineteenth century shopping passages. Journal of Cultural Heritage Management and Sustainable Development, 1(2), pp 135-156.

Plevoets, B. \& Van Cleempoel, K. 2013. Adaptive reuse as an emerging discipline: an historic survey. In: Cairns, G. (ed.) Reinventing architecture and interiors: a socio-political view on building adaptation. London: Libri Publishers.

Plevoets, B. \& Van Cleempoel, K. 2014. Aemulatio and the Interior Approach of Adaptive Reuse. Interiors: design, architecture, culture, 5(1), pp 71-88.

Public Architecture. 2010. Design for Reuse Primer. Available: http://www.publicarchitecture.org/reuse/pdf/Primer-Online.pdf [Accessed 7 November 2015].

Richards, J. 1994. Façadism. London: Routledge.

Rubessi, C. 2010. Sustainable practice in retail design: new functions between matter and space. IDEA Journal, 2010 (Interior Ecologies), pp. 78-79.

Saglar Onay, N. 2013. Commercial use of Antique interiors: dialectics of the contemporary and the conservative International Journal of Academic Research, 5(4), pp 161-168.

Sarnitz, A. 2003. Adolf Loos, 1870-1933: architect, cultural critic, dandy, Cologne: Taschen.

Schaefer, A. \& Crane, A. 2005. Addressing Sustainability and Consumption. Journal of Marcromarketing, 25(1), pp 76-92.

Scott, F. 2008. On Altering Architecture, London: Routledge. 
Sowinska-Heim, J. 2013. Conversions and Redefinitions - Architecture and Identity of a Place. Art Inquiry, Crossing Borders: Imagining Europe, Representing Periphery, pp. 191- 204.

Starn, R. 2002. Authenticity and historic preservation: towards an authentic history. History of the Human Sciences, 15(1), pp 1 - 16.

Starr, R. 2011. The certification of authenticity: effects on product perception. Doctoral thesis, University of Auckland.

Stovel, H. 2007. Effective use of authenticity and integrity as world heritage qualiifying conditions. City \& Time, 2(3), pp 21-36.

Theodoraki, A., Theodoraki - Patsi, J. \& Theodoraki, P. Restoration, Reconstruction and Simulacra. Comparative evaluation between Matera and Santorini. In: IAPS-CSBE \& HOUSING Networks, ed. Revitalising built environments, requalifing old places for new uses, 12-16 October 2009, Istanbul.

Thimothy, D. \& Boyd, S. W. 2003. The Authenticity Debate. Heritage tourism. Pearson Education.

Tucker, L. 2015. The relationship between historic preservation and sustainability in interior design. In: Thompson, J. \& Blossom, N. (eds.) The Handbook of Interior Design West Sussex: Wiley.

UNESCO. 2008. Opperational Guidelines for the Implementation of the World Heritage Convention. In: UNESCO (ed.). World Heritage Centre.

United Nations. 1987. Report of the World Commission on Environment and Development. Available: http://www.un-documents.net/wced-ocf.htm [Accessed 7 November 2015].

USGBC. 2010. Practical Strategies. Available: http://www.usgbc.org/Docs/Archive/General/Docs7760.pdf [Accessed 7 November 2015].

Van Cleempoel, K. 2008. The Relationship Between Contemporary Art and Retail Design. In: Peressut, L., Forino, I, Postiglione, G., Scullica, F. (eds.) Places and Themes of Interior. Milan: Interiors Studies Franco Angeli.

Van Tongeren, M. 2003. Retail Branding, Amsterdam: Bis Publishers.

Van Tongeren, M. 2004. Retail Branding. In: Christiaans, H. \& Van Amerongen, R. (eds.) Retail \& Interior Design. Rotterdam: Episode Publishers.

Warnaby, G. 2009. Look up! Retailing, historic architecture and city centre distinctiveness. Cities, 26(5), pp 287-292.

Webster, N. 1986. Authentic. In: Gove, P. (ed.) Webster's Third New International Dictionary. Springfield: Mass.

Yudelson, J. 2009. Sustainable Retail Development. New Success Strategies, Dordrechts: Springer. 